\title{
MENCIPTAKAN PERLINDUNGAN HUKUM YANG EFEKTIF BAGI HAK CIPTA KARYA SASTRA FILM NASIONAL : UTOPIS ATAU LOGIS?
}

\author{
Ayuta Puspa Citra Zuama \\ Magister Ilmu Hukum Universitas Sebelas Maret \\ J1. Ir. Sutami No.36, Kentingan, Kec. Jebres, Surakarta \\ E-mail: ayutapuspa@gmail.com
}

\begin{abstract}
The development of technology entering the era of the Internet of things does not only bring good news to human civilization, but also brings new modes and media for copyright infringers in national film literary works. Currently, film piracy media have started using a platform social media based on a private messaging service provider application called Telegram. Storywriters, Screenwriters, directors, producers, and film actors and actresses are disadvantaged by irresponsible public behavior in the form of piracy activities in the sense of making copies and distributing films in violation of applicable legal provisions. The legal provision in question is Law Number 28 of 2014 concerning Copyright, hereinafter referred to as UUHC. This regulation is the main legal umbrella for protecting the copyright of literary works including films in Indonesia. The Government's efforts to create legal protection for the copyright of national film literary works are continuously being developed to keep abreast of the modes and media used by copyright infringers. This article aims to find out how the current positive law regulates the aspects of copyright protection, especially for film literary works, then whether effective legal protection has been created for national film literary works in the country, and how the influence and relationship to community behavior is related to violations. copyright, especially film copyright. The research method used by the author in writing this article uses a type of normative research, namely by conducting a study of all formal legal regulations (laws and regulations below) that are relevant in relation to the topic of discussion, and using literatures that contain theoretical concepts for conduct an analysis of the subject matter of the research.
\end{abstract}

Keywords: protection, law, effective, copyright, film

\begin{abstract}
Abstrak
Perkembangan teknologi memasuki era Internet of things rupanya tidak hanya membawa berita baik bagi peradaban manusia, melainkan membawa pula modus dan media baru bagi para pelaku pelanggar hak cipta pada karya sastra film nasional. Media pembajakan film saat ini sudah mulai menggunakan platform media sosial berbasis aplikasi penyedia layanan perpesanan pribadi bernama Telegram. Para penulis cerita, penulis naskah/skenario, sutradara, produser, hingga para aktor dan aktris pemain film menjadi pihak yang dirugikan dengan adanya perilaku masyarakat yang tidak bertanggungjawab berupa kegiatan pembajakan dalam artian melakukan penggandaan, dan penyebaran film dengan melanggar ketentuan hukum yang berlaku. Ketentuan hukum yang dimaksud adalah Undang-Undang Nomor 28 Tahun 2014 tentang Hak Cipta yang selanjutnya akan disebut UUHC. Peraturan ini merupakan payung hukum utama bagi perlindungan terhadap hak cipta karya-karya sastra termasuk film di Indonesia. Upaya Pemerintah dalam menciptakan perlindungan hukum bagi hak cipta karya sastra film nasional terus dikembangkan guna mengikuti perkembangan modus serta media
\end{abstract}


yang digunakan para pelaku pelanggar hak cipta. Artikel ini bertujuan untuk mengetahui bagaimana hukum positif saat ini mengatur mengenai aspek perlindungan hak cipta khususnya bagi karya sastra film, kemudian apakah sudah tercipta perlindungan hukum yang efektif bagi karya sastra film nasional di tanah air, serta bagaimana pengaruh dan hubungannya terhadap perilaku masyarakat kaitannya dengan pelanggaran hak cipta khususnya hak cipta film. Metode penelitian yang digunakan penulis dalam menulis artikel ini menggunakan jenis penelitian normatif, yaitu dengan melakukan kajian terhadap seluruh peraturan hukum bersifat formil (Undang-Undang, dan peraturan dibawahnya) yang relevan kaitannya terhadap topik bahasan, serta menggunakan literatur-literatur yang berisi konsep teoritis untuk melakukan analisa terhadap pokok permasalahan penelitian.

Kata Kunci: perlindungan, hukum, efektif, hak cipta, film

\section{A. Pendahuluan}

Problematika sosial terkait dengan munculnya kegiatan pembajakan karya sastra berupa film di tanah air sudah menjadi masalah lama yang tidak kunjung terselesaikan. Pembajakan karya-karya berharga para sineas asli Indonesia kian hari justru kian bertambah dan mengkhawatirkan. Para penulis cerita, penulis naskah/skenario, sutradara, produser, hingga para aktor dan aktris pemain film menjadi pihak yang dirugikan dengan adanya perilaku masyarakat yang tidak bertanggungjawab berupa kegiatan pembajakan dalam artian melakukan penggandaan, dan penyebaran film dengan melanggar ketentuan hukum yang berlaku. Hal ini dikarenakan ketika pembajakan terjadi, maka hak ekonomi berupa royalty dari hasil penjualan, penayangan, ataupun pemanfaatan karya film beralih dari sang pencipta yang mestinya memiliki hak tersebut kepada oknum masyarakat pembajak film pelanggar ketentuan hukum yang berlaku. ${ }^{1}$ Ketentuan hukum yang dimaksud adalah Undang-Undang Nomor 28 Tahun 2014 tentang Hak Cipta yang selanjutnya akan disebut UUHC. Peraturan ini merupakan payung hukum utama bagi perlindungan terhadap hak cipta karya-karya sastra termasuk film di Indonesia.

Hak cipta dapat dimaknai sebagai suatu hak eksklusif yang dimiliki oleh sang pencipta karya atau disebut juga sebagai pemegang hak cipta untuk dapat melakukan kontrol penuh atas karya ciptaannya. Hak cipta yang tertera dalam Pasal 4 UUHC terdiri atas hak ekonomi dan hak moral yang akan melekat secara otomatis tanpa harus dilakukan pendaftaran terlebih dahulu sejak sebuah karya tercipta. ${ }^{2}$ Hak ekonomi adalah hak bagi pencipta untuk memperoleh nilai ekonomis dari hasil pendayagunaan karya ciptaannya. Sementara hak moral merupakan hak istimewa yang akan terus melekat pada sebuah karya, tidak bisa hilang meskipun sang pencipta meninggal dunia, dan tidak pula dapat beralih tanpa adanya wasiat dari pemegang hak cipta yang sah. ${ }^{3}$ Hak moral merupakan garansi bagi sang pencipta agar namanya turut disebutkan setiap terdapat pihak-pihak yang menggunakan hasil karya

$1 \quad$ Oksidelfa Yanto, "Konsep Perlindungan Hak Cipta dalam Ranah Hukum Hak Kekayaan Intelektual (Studi Kritis Pembajakan Karya Cipta Musik dalam Bentuk VCD dan DVD)" Yustitia Jurnal Fakultas Hukum Universitas Sebelas Maret, 04(03), 2015, hlm. 4

2 Ras Elyta Ginting, Hukum Hak Cipta Indonesia (Analisis Teori dan Praktik), Bandung: Citra Aditya Bakti, 2012, hlm. 64

3 Budi Santoso, HKI Hak Kekayaan Intelektual, Semarang: Penerbit Pustaka Magister, 2011, hlm. 98-100 
Ayuta Puspa Citra Zuama. Menciptakan Perlindungan Hukum yang Efektif...

cipta nya dengan memperoleh izin terlebih dahulu darinya. ${ }^{4}$ Hak cipta milik pemegang hak cipta ini juga berfungsi sebagai alat yang dapat membatasi penggunaan karya, serta mencegah pendayagunaan yang tidak sah atas karya cipta tersebut. ${ }^{5}$

Setiap karya sastra memiliki hak cipta sejak ia diciptakan. Termasuk pula karya-karya berupa film tentunya juga melekat hak cipta dan masuk sebagai objek yang dilindungi oleh UUHC. Namun keberadaan UUHC yang bahkan telah mengalami beberapa kali revisi demi penyempurnaan ketentuan didalamnya belum juga mampu menciptakan perlindungan hukum yang efektif bagi hak cipta pada karya sastra film nasional. Salah satu perubahan mendasar pada UUHC ini dilakukan perubahan jenis delik perlindungan hak cipta. Perlindungan terhadap hak cipta saat ini merupakan delik aduan, dari yang semula merupakan delik biasa. ${ }^{6}$ Dimana perubahan ini disebabkan karena hak cipta pada prinsipnya adalah hak yang bersifat privat. ${ }^{7}$ Kejahatan terhadap Hak Cipta setelah adanya revisi UUHC Tahun 2014, aparat penegak hukum hanya akan menindak kejahatan hak cipta berdasarkan aduan dari pihak yang dirugikan. Apabila tidak ada pihak yang mengadu, implikasinya maka oknum pelanggar hak cipta ini akan bebas melakukan aktivitas pembajakan. ${ }^{8}$ Meskipun demikian sebagai solusi, pemerintah telah memberikan akses yang mudah bagi pemegang hak cipta untuk mengajukan pengaduan ke Ditjend HKI apabila terdapat pelanggaran hak cipta yang merugikan dan kemudian pemerintah melalui penegak hukum akan melakukan inspeksi mendadak ataupun pemblokiran dan penutupan laman website yang telah terbukti melakukan pelanggaran Hak Cipta.

Dari masa ke masa perilaku pembajakan justru mengalami perkembangan baik dalam segi kuantitas, maupun modus pembajakannya. Apabila dulu aktivitas pembajakan film dapat dilihat secara nyata dengan beredarnya VCD/ DVD bajakan yang dijual di pasar ataupun toko, yang kemudian dapat terjaring oleh razia penegak hukum, maka saat ini di era berkembangnya teknologi, media penyebaran film bajakan semakin beragam. Mulai dari situs website film gratis, ${ }^{9}$ yang juga sudah diupayakan pemerintah dengan melakukan penutupan laman website yang bersangkutan, hingga kini muncul penyebaran film bajakan melalui media sosial berbasis aplikasi penyedia layanan private chat/ perpesanan pribadi yang popular dikenal dengan nama "Telegram".

Perkembangan era digital turut menuntun peradaban manusia untuk terus menciptakan inovasi-inovasi modern guna memudahkan tiap aktivitas yang dijalani sehari-hari. Inovasi yang diciptakan guna menunjang cara berinteraksi, serta melakukan kegiatan sosial adalah lahirnya perkembangan teknologi di bidang telekomunikasi berupa media sosial. ${ }^{10}$ Telegram

4 Henry Soelistyo, Hak Cipta Tanpa Hak Moral, Jakarta: PT. Raja Grafindo Persada, 2011, hlm. 14.

5 Haris Munandar dan Sally Sitanggang, Mengenal HAKI Hak Kekayaan Intelektual, Jakarta: Penerbit Erlangga, 2011, Hlm. 16

6 Mega Silvana Kurniawati, "Konsekuensi Perubahan Sifat Delik Pelanggaran Hak Cipta Terhadap Perlindungan Pencipta Menurut Undang-Undang Nomor 28 Tahun 2014 Tentang Hak Cipta”, (Skripsi Fakultas Hukum Universitas Atma Jaya Yogyakarta), 2016, hlm. 4

7 Wempi JH Kumendong, “Kemungkinan Penyidikan Delik Aduan Tanpa Pengaduan”, Jurnal Hukum Universitas Sam Ratulangi, Volume 23, Nomor 9, April 2017.

8 Thalib Prawitri, "Perlindungan Hukum Terhadap Pemegang Hak Cipta dan Pemilik Lisensi Rekaman Berdasarkan UndangUndang Tentang Hak Cipta.” Jurnal Yuridika. Vol 23 No. 8, September-Desember 2013, hlm. 357-360

9 Irham Nur Anshari, Memahami Pembajakan Digital Dalam Budaya Mengopi Video di Warnet, Yogyakarta: Universitas Ahmad Dahlan, 2016, hlm 171.

10 Bimo Mahendra, "Eksistensi Sosial Remaja Dalam Instagram (Sebuah Perspektif Komunikasi), Jurnal Visi Komunikasi 
menjadi salah satu platform media sosial berbasis aplikasi penyedia jasa pengiriman pesan pribadi yang cukup digemari oleh masyarakat. Penggunaannya cukup mudah dan dapat didownload secara resmi melalui laman resmi nya untuk di gunakan pada smartphone berbasis Android dan IOS, Personal Computer, dan juga dapat dioperasikan langsung lewat website. Telegram menjadi aplikasi perpesanan yang unggul karena dilengkapi dengan Fitur-fitur istimewa seperti grup dan channel yang dapat menampung anggota dengan jumlah tidak terbatas, serta fitur file sharing dengan limit kapasitas yang lebih tinggi dari limit yang mampu diberikan oleh aplikasi pesaingnya. ${ }^{11}$

Sayangnya keberadaan fitur-fitur yang dapat memberikan kemudahan untuk melakukan pengiriman file, link website, dan juga menambah anggota grup, membuat grup dan channel, serta bergabung ke suatu grup dan channel yang diinginkan dengan mudah justru menjadi celah yang banyak dimanfaatkan oleh para pembajak film era saat ini. Banyak sekali pembajak film yang membagikan file film-film bajakan melalui channel atau grup yang dibuatnya dalam platform telegram ini. Para pelaku pembajakan film kebanyakan membuat channel telegram kemudian menamai channel tersebut sesuai judul film yang bersangkutan agar memudahkan orang-orang untuk bergabung ke dalam channel tersebut. Para pengguna Telegram hanya perlu mengetikkan judul film yang dicarinya dalam kolom pencarian, kemudian memencet menu 'bergabung' yang telah tersedia. Dengan begitu para pembajak mendapatkan anggota channel bajakan film yang dibuatnya.

Kasus yang masih hangat dan cukup menggemparkan jagad dunia maya adalah kasus pembajakan film karya sutradara Angga Dwimas Sasongko yang mengungkapkan kekecewaannya atas pembajakan karya terbarunya yang berjudul "Story of Kale: When Someone in Love". ${ }^{12}$ Sebagai salah satu sineas tanah air yang terus produktif walau pada masa pandemi covid 19, Angga tetap melaksanakan peluncuran perdana film barunya ini melalui platform bioskop digital buatannya sendiri untuk menyiasati kondisi dimana bioskop layar lebar saat ini tengah tutup.

Melalui laman website bioskoponline.com sutradara kondang ini memberi inovasi baru dalam dunia hiburan bagi masyarakat Indonesia yang ingin menonton film karya sutradara-sutradara terbaik tanah air dari rumah masing-masing selama masa pandemi. Tarif yang dikenakan untuk satu film pun cukup terjangkau. Hanya berkisar Rp. 5.000,00 hingga Rp.10.000,00 saja penonton sudah dapat menonton film secara legal. Kemurahan hati Angga ini justru memberikan gagasan bagi para pembajak film untuk melangsungkan aksinya. Beberapa orang dengan akun yang telah terdaftar dalam laman website bioskop digital tersebut rupanya telah melakukan penggandaan film secara ilegal, kemudian menyebarkannya melalui platform-platform digital penyedia film gratis termasuk melalui aplikasi telegram.

Uraian singkat salah satu kasus pembajakan film yang baru saja terjadi sekitar akhir bulan Oktober 2020 tersebut dapat dikategorikan sebagai sebuah pelanggaran hak cipta

Volume 16, Nomor 01, Mei 2017, hlm. 152.

11 Hari Widowati, “10 Keunggulan Telegram Aplikasi Perpesanan Pesaing Whatsapp”, 23 Mei 2019, https://katadata.co.id/ hariwidowati/digital/5e9a518a845d1/ini-10-keunggulan-telegram-aplikasi-perpesanan-pesaing-whatsapp, diakses pada 29 Desember 2020.

12 Retia Kartika Dewi, "Sutradara Story of Kale akan Polisikan Pembajak Film ini Sanksi Hukumnya", 27 Oktober 2020, https:/www.kompas.com/tren/read/2020/10/27/215706265/sutradara-story-of-kale-akan-polisikan-pembajak-film-inisanksi-hukumnya?page=all, diakses pada 22 Desember 2020 . 
dalam jaringan internet. Selain melanggar UUHC, Undang-Undang Nomor 11 Tahun 2008 Jo. Undang-Undang Nomor 19 Tahun 2016 tentang Informasi dan Transaksi Elektronik, yang selanjutnya disebut UU ITE juga turut mengambil peranan penting. Pasal 25 UU ITE pada intinya memberikan justifikasi bagi karya-karya intelektual yang berbentuk dokumen elektronik atau berbentuk transmisi elektronik sebagai objek yang juga dilindungi oleh rezim UUHC. Selain itu, peraturan ini juga memberikan rincian aturan yang lebih spesifik mengenai hak serta kewajiban atas pengiriman/penyebaran dan penerimaan informasi berupa data elektronik melalui jaringan internet. Keberadaan hak cipta dalam ruang dunia digital menjadikan UUHC saling memiliki keterkaitan dengan UU ITE.

Bentuk pelanggaran terhadap hak cipta pada prinsipnya memiliki dua ciri utama. Ciri pertama adalah adanya unsur kesengajaan dan tanpa hak melakukan pengumuman, penggandaan, atau pemberian izin untuk hal tersebut. Kedua, dengan adanya unsur kesengajaan dalam memamerkan, menyebarluaskan, atau menjual kepada khalayak publik suatu karya cipta yang masih dilekati hak cipta penciptanya. ${ }^{13}$ Keberadaan UUHC dan UU ITE sebagai payung hukum perlindungan terhadap Hak Cipta terutama dalam era digital saat ini saja belum mampu memberantas tuntas aktivitas pembajakan di Indonesia. Aktivitas pembajakan yang terus menjadi fenomena ditengah masyarakat, bahkan kian hari kian meningkat hingga menjadi trend tersendiri untuk memproduksi serta menikmati filmfilm bajakan. Hal ini sungguh merupakan suatu ironi. Serangkaian aktivitas pembajakan film yang tidak bertanggungjawab kemungkinan dapat timbul sebagai akibat dari desakan faktor hak ekonomi yang menjanjikan keuntungan bagi beberapa pihak terkait. Serta kemungkinan juga dapat disebabkan oleh kurangnya kesadaran dan ketaatan masyarakat terhadap ketentuan hukum yang berlaku. ${ }^{14}$

Berdasarkan uraian singkat pendahuluan tersebut, menjadi menarik untuk melakukan penelitian terhadap perlindungan hukum bagi hak cipta khususnya pada karya sastra film nasional untuk mengetahui bagaimana perlindungan hukum yang dijamin negara saat ini bagi para pemegang hak cipta karya sastra film, serta bagaimana tingkat efektivitas perlindungan hukum bagi hak cipta karya sastra film nasional yang sudah ada saat ini. Apakah menciptakan suatu perlindungan hukum yang efektif bagi hak cipta karya sastra film nasional di tengah era perkembangan digital saat ini merupakan suatu gagasan yang utopis atau logis?

Utopis menurut Kamus Besar Bahasa Indonesia dapat diartikan sebagai kondisi yang khayal, impian yang terlalu tinggi, atau sesuatu yang sulit untuk diwujudkan. Sementara sebaliknya pemaknaan logis disini dapat diartikan sebagai upaya untuk menciptakan perubahan yang mampu dicapai, dapat bersifat benar atau nyata sesuai dengan penalaran dan logika pemikiran manusia. Sehingga penelitian dalam artikel ini bertujuan untuk mengetahui apakah cita hukum yang terkandung dalam seperangkat peraturan perundangundangan terkait dengan perlindungan hak cipta karya film dapat benar-benar diwujudkan atau hanya sekedar gambaran utopia yang ada di angan-angan.

Metode penelitian yang digunakan penulis dalam menulis artikel ini menggunakan jenis penelitian normatif, yaitu dengan melakukan kajian terhadap seluruh peraturan hukum

13 Muhammad Djumhana, Hak Milik Intelektual Sejarah, Teori dan Prakteknya di Indonesia, Bandung: PT Citra Aditya Bakti. 2003, Hlm. 119.

14 Hasbir, Analisis Aspek Sosiologi Hukum Terhadap Pelanggaran Hak Cipta Rekaman Suara (lagu) di Kota Makassar, 2002, Tesis Hal. 3. 
bersifat formil (Undang-Undang, dan peraturan dibawahnya) yang relevan kaitannya terhadap topik bahasan, serta menggunakan literatur-literatur yang berisi konsep teoritis untuk melakukan analisa terhadap pokok permasalahan penelitian. ${ }^{15}$

\section{B. Pembahasan}

\section{Perlindungan Hukum Bagi Hak Cipta Karya Sastra Film Nasional}

Karya sastra film merupakan salah satu objek yang dilindungi oleh UUHC dalam kaitannya dengan melekatnya hak cipta pada tiap karya film yang telah diciptakan kreatornya. Pada era digital saat ini dimana teknologi semakin berkembang dan telah memasuki babak internet of things, modus, media serta teknik pembajakan film juga turut berkembang. Kegiatan pembajakan film disini yang dimaksud adalah aktivitas tidak bertanggungjawab yang dilakukan seseorang untuk menggandakan dan menyebarkan karya sastra berupa film melalui cara-cara yang menentang ketentuan hukum yang berlaku. Perkembangan jenis media dalam melakukan pembajakan film saat ini sudah bukan hanya melalui VCD/DVD, laman website streaming/download film gratis, saat ini muncul media baru yang digunakan sebagai sarana penyebaran film bajakan/ film yang telah digandakan dan disebarluaskan tanpa izin pemegang hak cipta.

Perbuatan menduplikasi, mengunduh data berisi karya film kemudian menyebarkannya begitu mudah dilakukan melalui akses dunia internet, apalagi dipermudah dengan fitur-fitur yang ditawarkan aplikasi media sosial berbasis penyedia layanan perpesanan pribadi "Telegram" yang memang memberikan fasilitas pengiriman/ pengunggahan data melalui chat sebesar maksimal 2GB dari yang semula sudah 1,5GB. Belum lagi adanya fitur grup dan channel yang tidak terbatas jumlah anggotanya, hal ini akan mempermudah penyebaran konten yang dikehendaki. Bagi para pembajak, media ini menjadi media yang sempurna untuk meraih keuntungan ekonomis dengan mengenakan tarif untuk join/masuk ke grup atau channel tertentu. Ada juga pembajak yang tidak mengejar keuntungan ekonomis dan memang hanya mengejar kepuasan diri dengan menybarkan hiburan gratis yang tidak legal. Fenomena pembajakan ini tentu menyebabkan kerugian bagi para pencipta karya atau pemegang hak cipta. Berikut merupakan uraian singkat mengenai konsep pentingnya perlindungan hak cipta dan upaya perlindungan hukum terhadap pelanggaran hak cipta.

Hak cipta adalah salah satu bagian dari objek hak kekayaan intelektual (HKI). Pada prinsipnya HKI adalah sebuah bentuk apresiasi yang dianugerahkan pemerintah kepada masyarakat dengan kemampuan menghasilkan sebuah kreasi baik dalam bentuk penemuan sederhana, cipta karya hingga karya seni dan sastra. ${ }^{16}$ Mengapa kemudian hak cipta menjadi salah satu hak yang mendapat prioritas perlindungan hukum, dapat dijawab dengan kumpulan beberapa teori yang mendukung pentingnya hak cipta untuk dilindungi ${ }^{17}$ :

a. Theory of Reward, pencipta atau penemu berhak mendapat suatu penghargaan atas usaha yang telah ia lakukan.

15 Peter Mahmud Marzuki, Penelitian Hukum, Jakarta: Kencana Prenadamedia, 2018. Hlm.15

16 Anak Agung Mirah Satria Dewi, "Perlindungan Hukum Hak Cipta Terhadap Cover Version Lagu di Youtube" Jurnal Magister Hukum Udayana, 06(04), 2017, hlm.2

17 Cintya Farha Indah, "Perlindungan Hukum Pemegang Hak Cipta Terhadap Situs Film Gratis di Internet”, Jurnal Unisma, Vol. 1 (2020), hlm. 3-4 
b. Theory of Recovery, pencipta yang telah mengeluarkan waktu, tenaga, pikiran, bahkan biaya yang tidak sedikit sehingga perlu diberikan imbalan atas hasil karyanya, baik berupa perlindungan hukum atas karyanya ${ }^{18}$ maupun penebusan atas usaha yang telah dilakukan, yang dapat berbentuk suatu penemuan berharga bagi publik.

c. Theory of Incentive, sebuah hasil karya kreativitas seseorang membutuhkan insentif untuk memberi motivasi dan melanjutkan penelitian yang dapat bermanfaat.

d. Theory of Risk, suatu proses penciptaaan karya selalu mengandung sebuah resiko. Karenanya sangat dibutuhkan perlindungan dalam tiap proses yang mengandung resiko tersebut.

e. Theory of The Economic Growth Stimulus, teori ini berdasarkan Hak Milik Intelektual merupakan alat pembangun ekonomi. Sebuah sitem HKI yang efektif akan memciptakan stimulus ekonomi dalam suatu negara.

Memaknai perlindungan hukum dapat diartikan sebagai suatu upaya yang dianugerahkan kepada suatu subyek hukum tertentu oleh negara melalui dibentuknya serangkaian peraturan perundang-undangan yang akan diberlakukan sebagai hukum negara lengkap dengan keberadaan sanksi yang berfungsi sebagai ancaman dan diharap mampu mendatangkan deterence effect bagi para pelaku nya. Perlindungan hukum dalam bentuk hukum positif akan menjamin kepastian, kemanfaatan, dan keadilan hukum sebagaimana tujuan dibentuknya hukum. Secara garis besar perlindungan hukum yang diberikan pemerintah melalui tameng hukum berupa peraturan ini akan menghadirkan dua fungsi sekaligus. Yaitu, baik sebagai upaya Preventif maupun sebagai upaya Represif.

Preventif disini maksudnya perlindungan yang diberikan bertujuan untuk mencegah atau menjauhkan perilaku-perilaku masyarakat agar tidak melakukan pelanggaran hukum berupa pembajakan film melalui media internet, lebih khususnya melalui media sosial private chat Telegram. Upaya pencegahan diharapkan mampu mengurangi kasus pembajakan yang dilakukan masyarakat Indonesia. Kehadiran UUHC yang terus disempurnakan pemerintah hingga yang terakhir diberlakukan sejak tahun 2014 lalu dapat diartikan sebagai upaya preventif dalam mencegah terjadinya pembajakan film. Karena dalam peraturan perundangan tersebut jelas terdapat ancaman sanksi yang bahkan menghadirkan ancaman sanksi pidana sehingga memang bertujuan untuk memberi deterrence effect atau efek yang menimbulkan ketakutan bagi calon pelakunya.

Selain itu untuk memberikan perlindungan yang lebih optimal, pemerintah juga telah membentuk sebuah Peraturan Bersama Menteri Hukum dan HAM Nomor 14 Tahun 2015 serta juga membuat Peraturan Menteri Kominfo Nomor 26 Tahun 2015 tentang Pelaksanaan Penutupan Konten dan/atau hak akses pengguna yang melanggar hak cipta dan/atau hak terkait dalam sistem elektronik. Tegas dalam pasal 15 tertuang bahwa penutupan konten dan/atau hak akses pengguna yang melanggar hak cipta dan/atau hak terkait akan diumumkan dalam laman resmi kementerian yang menyelenggarakan urusan pemerintahan di bidang komunikasi dan informatika. Ancaman berupa

18 Aan Priyatna, Penegakan Hukum terhadap Pelanggaran Hak Cipta dalam Pembuatan E-book, Semarang: Universitas Diponegoro, 2016, hlm. 7. 
penutupan kontek dan atau hak akses ini juga dapat digunakan sebagai upaya preventif untuk memerangi para pembajak film. Sehingga ketika nantinya kementerian hukum dan HAM melalui bantuan rekomendasi berdasarkan pelaporan yang masuk ataupun pengamatan langsung dari Ditjen Kekayaan Intelektual maupun pengamatan langsung dari kementerian terkait dapat memerintahkan kementerian bidang kominfo untuk melakukan penutupan konten, kanal/media dan/atau hak akses pengguna yang telah sah ditentukan melanggar ketentuan Hak Cipta dan/atau Hak Terkait didalam lingkup sistem berbasis elektronik/ digital. ${ }^{19}$

Selain kedua peraturan tersebut karena media yang digunakan berbasis internet atau aplikasi yang menggunakan internet UU ITE juga mengandung ancaman bagi para pelaku pembajakan film melalui media digital. Undang-undang Nomor 11 Tahun 2008 tentang Informasi dan Transaksi Elektronik. Memberikan perlindungan bagi pencipta atau pemegang hak cipta dalam hal ini tepatnya dalam ketentuan yang tertuang pada Pasal 32 Ayat (1) Pasal ini ditujukan kepada seseorang dengan unsur kesengajaan berniat melakukan tindakan pengubahan, penambahan, pengurangan, perusakan, penghilangan, penyembunyian, dan pengiriman data dari suatu sumber data kepada para penerima data suatu informasi elektronik yang berupa satu atau sekumpulan data elektronik, termasuk tetapi tidak terbatas pada tulisan suara, gambar, peta, rancangan, foto, electronik data interchange, surat elektronik, telegram, teks dan lainnya dan/atau dokumen pribadi berupa informasi elektronik yang dibuat diteruskan, dikirimkan, diterima atau disimpan dalam bentuk analog, digital, elektromagnetik, optikal atausejenisnya, milik seseorang secara pribadi atau milik publik.

Beberapa peraturan yang telah diuraikan diatas sengaja dibentuk oleh pemerintah dengan berbagai ketentuan didalamnya bukan hanya mengandung upaya preventif semata. Hadirnya peraturan-peraturan sebagaimana telah diuraikan tersebut tentu juga membawa upaya represif berupa penegakan ketentuan sanksi yang diatur sebagai perlindungan terakhir bagi para pemegang hak cipta dengan benar-benar menjatuhkan hukuman kepada pelaku yang telah terbukti melakukan pelanggaran hak cipta berdasarkan putusan hakim Pengadilan Niaga. ${ }^{20}$ secara lebih rinci, upaya represif bagi para pelanggar ketentuan hukum hak cipta dapat ditempuh melalui tiga jenis hukum. Yaitu jalur hukum perdata, pidana, maupun administratif. Melalui upaya hukum perdata, para pelaku pelanggar hak cipta dapat dilayangkan gugatan berupa gugatan Perbuatan Melanggar Hukum berdasarkan Pasal 1365 KUH Perdata. Penggugat nantinya harus mampu membuktikan bahwa perbuatan pelaku telah merugikan penggugat sebagaimana tertuang dalam ketentuan Peraturan Bersama Menteri Hukum dan HAM Nomor 14 Tahun 2015 serta Menteri Kominfo Nomor 26 Tahun 2015 tentang Pelaksanaan Penutupan Konten dan/atau Hak Akses Pengguna Pelanggaran Hak Cipta dan/atau Hak Terkait dalam Sistem Elektronik yang mengatur mengenai bagaimana prosedur pengaduan tindakan pelanggaran Hak Cipta kepada menteri terkait.

Upaya administratif dapat ditempuh pemegang hak cipta melalui pelaporan kepada Dirjen Kekayaan Intelektual. Sebelum melayangkan aduan/ Laporan kepada Ditjen KI,

19 Ahmad M. Ramli, September 2018 "Perlindungan Hak Cipta Terhadap Film Berdasarkan Undang-Undang Nomor 28 Tahun 2014" online document, http://docplayer.info/storage/70/6231381/62131381.pdf, hlm. 17 diakses 27 Desember 2020.

20 Muchsin, Perlindungan dan Kepastian Hukum bagi Investor Indonesia. Surakarta: Fakultas Hukum Sebelas Maret, 2003, Hlm. 14. 
para pencipta atau pemegang hak cipta hendaknya terlebih dahul memberikan somasi/ peringatan kepada pelaku yang diduga melakukan pelanggaran Hak Cipta. Pelanggaran yang dimaksud disini adalah pelanggaran dengan tujuan komersialisasi untuk memperoleh hak ekonomis dari ciptaan yang bukan menjadi Hak ciptanya. Melainkan hak cipta tersebut merupakan milik pemegang hak cipta yang masih sah dan berlaku. Laporan diajukan secara tertulis menggunakan bahasa indonesia yang baik dan benar kepada Direktur Jenderal Kekayaan Intelektual. Laporan harus memuat sedikitnya identitas pelapr, bukti atas hak ciptaan, alamat situs/ akun pelanggar, jenis konten pelanggar, dan jenis pelanggaran. Dilampiri dengan fotokopi identitas pelapor, fotokopi bukti kepemilikan $\mathrm{HC}$ atau dokumen terkait, dan laporan harus diberikan dalam bentuk hardcopy non elektronik dialamatkan kepada DitJend HKI. Sanksi administratif yang akan dijatuhkan kepada pelanggar hak cipta khususnya dalam kegiatan pembajakan film biasanya mengacu pada ketentuan perundangan yang berlaku, dapat berupa denda, pembekuan hingga pencabutan sertifikat dan/atau izin usaha, penghentian sementara pelayanan administrasi, dan kemungkinan dapat berupa penutupan situs, atau penutupan akun media sosial pelaku. ${ }^{21}$

Sementara secara hukum pidana bagi para pelanggar hak cipta tentu sanksi pidana penjara maupun pidana denda telah menanti didepan mata. UUHC secara tefas mengatur dalam Pasal 113 hinga 119 mengenai ketentuan sanksi pidana. Deretan pasal tersebut berisi ketentuan berupa ancaman sanksi pidana bagi pelaku, dengan skala bergantung pada besar kecilnya akibat tindakan pelaku. Meskipun khusus untuk penyelesaian perkara pidana di bidang pelanggaran hak cipta, UUHC dalam Pasal 95 Ayat (4) memberikan alternatif penyelesaian sengketa melalui mediasi apabila disepakati oleh para pihak. $^{22}$

Berbagai upaya perlindungan hukum baik yang bersifat preventif maupun represif sebagaimana telah diuraikan diatas harus diakui telah dilaksanakan sejauh ini setidaktidaknya efektif dilakukan pemerintah mulai tahun 2014 sejak UUHC terbaru disahkan dan diberlakukan. Upaya pencegahan dan penindakan terhadap para pelaku kejahatan hak cipta selama ini dapat dirasa masih sangat kurang kuat dan belum mampu memberi efek jera bagi para pelaku kejahatan terhadap hak cipta, khususnya hak cipta karya cipta film, yaitu para pembajak film di Indonesia karena penegakan upaya-upaya trsebut belum maksimal. ${ }^{23}$ Karenanya hal yang perlu dibenahi dari pelaksanaan selama ini adalah menguatkan unsur penegakan hukum negara. Menurut Prof. Satjipto Rahardjo, yang dimaksud dengan unsur penegakan hukum adalah serangkaian proses yang terdiri dari penjabaran gagasan dan cita hukum suatu negara yang berdaulat yang didalamnya meliputi moral bangsa seperti prinsip keadilan dan prinsip menjunjung kebenaran dalam sebuah gambaran yang riil. Untuk mewujudkan serangkaian proses tersebut maka dibutuhkan penguatan terhadap organisasi yang memegang tugas sebagai

21 Daniel Andre Stefano, Hendro Saptono, dan Siti Mahmudah, "Perlindungan Hukum Pemegang Hak Cipta Film Terhadap Pelanggaran Hak Cipta Yang Dilakukan Situs Penyedia Layanan Film Streaming Gratis di Internet Menurut UndangUndang Nomor 28 Tahun 2014 Tentang Hak Cipta”, Diponegoro Law Journal, Volume 5 Nomor 3, Tahun 2016, hlm. 7.

22 Nevey Varida Ariani, “Alternatif Penyelesaian Sengketa Bisnis Di Luar Pengadilan”, Jurnal Rechts Vinding Volume 1, Nomor 2, Agustus 2012, hlm. 4.

23 Fransin Miranda Lopes, “Penegakan Hukum Terhadap Pelanggaran Hak Cipta di Bidang Musik dan Lagu”, Jurnal Hukum, vol. 1 No. 2, Juni 2015, hlm. 48. 
penegak hukum negara seperti kejaksaan, lembaga pemasyarakatan, pengadilan, serta kepolisian. $^{24}$

Selain itu problematika selanjutnya yang akan menghadang dimasa mendatang adalah apabila memandang dan memppertimbangkan progresifitas hukum mengenai dinamika perkembangan pembentukan hukum di Indonesia, di mana akan dibentuknya Undang-Undang Perlindungan Data Pribadi selanjutnya disebut UU PDP, yang mana kemungkinan salah satu cakupannya adalah ruang privat dari pengguna media sosial, khususnya media sosial berbasis aplikasi penyedia jasa layanan private chat, akan menjadi tantangan hukum tersendiri. Saat ini ketika UU PDP belum ada dan masih diwacanakan, pemerintah masih memiliki wewenang untuk melakukan tindakan langsung memblokir/ menutup channel/grup Telegram pengguna media sosial berbasis layanan perpesanan privat tersebut dengan bebas dan efektif. Berbeda hal nya ketika nanti terdapat peraturan yang memberikan proteksi bagi ruang privat seseorang. Akankah pemerintah masih dapat masuk kedalam akses privat untuk melakukan sortir konten-konten yang bersifat melanggar Hak Cipta, atau senantiasa nantinya pergerakan pemberantasan pelanggaran hak cipta akan semakin menuai problematika karena terbentur tembok privat hingga menyebabkan kegiatan pembajakan film semakin memperlebar sayapnya.

\section{Tinjauan Mengenai Efektivitas Perlindungan Hukum bagi Hak Cipta Karya Sastra Film Nasional}

Mengukur efektivitas suatu peraturan perundang-undangan tidak dapat terpisahkan dari perilaku masyarakat akan kesadaran dan ketaatannya terhadap hukum. Kedua unsur perilaku masyarakat tersebut, yaitu kesadaran, dan ketaatan sering dicampur adukkan dalam memahaminya. Mestinya tidak seperti itu. Karena meskipun keduanya memiliki hubungan keterkaitan yang erat dalam menentukan tingkat efetivitas suatu peraturan perundang-undangan, namun keduanya memiliki makna yang berbeda. ${ }^{25}$

Kesadaran hukum merupakan suatu prinsip sadar atau semacam nilai di dalam diri seseorang akan keberadaan suatu hukum yang berlaku, akan suatu hukum yang diharapkan ada, akan fungsi hukum yang hendaknya dijalankan hukum dalam masyarakat. ${ }^{26}$ Sehingga secara sederhana kesadaran hukum belum mampu melahirkan jaminan bahwa masyarakat akan selalu menaati suatu peraturan perundang-undangan. Sebagai analogi sederhana, seseorang yang sadar bahwa sesuatu hal merupakan benda/ aktivitas yang dilarang oleh hukum, misalkan mengetahui narkoba adalah obat terlarang saja tidak serta merta menghentikan seorang pecandu dari mengkonsumsi obat-obatan terlarang tersebut.

Berkaitan dengan uraian mengenai kesadaran hukum tersebut, maka Oetojo Oesman (dalam Acmad Ali) membedakan kesadaran hukum menjadi dua jenis yaitu ${ }^{27}$ :

\footnotetext{
24 M. Husein Maruapey, "Penegakan Hukum dan Perlindungan Negara", Jurnal Ilmu Politik dan Komunikasi, Volume VII, Nomor 1, Juni 2017, hlm. 24.

25 Achmad Ali, Menjelajahi Kajian Empiris Terhadap Hukum. Jakarta: PT. Yarsif Watampone. Hlm. 191

26 Ibid, hlm.192

27 Ibid. Hal. 192
} 
a. Kesadaran hukum baik;

b. Kesadaran hukum buruk. Yaitu ketika seseorang semakin memiliki pengetahuan akan hukum, semakin mengetahui celah/fungsi hukum misalnya karena mengetahui kemungkinan penggunaan upaya hukum banding dan juga kasasi, meskipun orang tersebut sadar betul akan posisinya bahwa ia berada pada pihak yang salah, ia akan menggunakan kesempatan upaya hukum tersebut. Jenis kesadaran hukum buruk ini dapat dikatakan sebagai salah satu dari faktor-faktor penyebab penumpukan perkara di MA.

Sementara menurut Soerjono Soekanto, beliau berpendapat, bahwa dalam memahami kesadaran hukum terdapat empat unsur penting yang mesti ada didalamnya, yaitu sebagai berikut ${ }^{28}$ :

a. Pengetahuan hukum;

b. Pengetahuan akan isi hukum;

c. Sikap hukum;

d. Pola perilaku hukum.

Demikian beberapa pendapat pakar sosiologi hukum dalam memahami apa yang dimaksud dengan kesadaran hukum. Selanjutnya mengenai makna dari ketaatan hukum dan perbedaannya dengan kesadaran hukum yang telah dibahas sebelumnya adalah sebagai berikut. Ketaatan hukum menurut H.C. Kelman (dalam Achmad Ali) berdasarkan kuantitasnya dapat dikategorikan ke dalam tiga jenis, yaitu ${ }^{29}$ :

a. Ketaatan bersifat Compliance, ketaatan terhadap suatu aturan yang dilandasi oleh rasa takut akan terkena sanksi apabila melanggar aturan yang bersangkutan;

b. Ketaatan bersifat Identification, ketaatan terhadap suatu aturan yang dilandasi oleh rasa takut akan rusaknya hubungan baik dengan orang lain apabila tidak menjalankan aturan tersebut dengan taat.

c. Ketaatan bersifat Internalization, ketaatan terhadap suatu aturan dilandasi kesesuaian antara nilai-nilai interinsik yang dipercayainya dengan aturan tersebut.

Sehingga dapat disimpulkan bahwa perbedaan antara kesadaran hukum dengan ketaatan hukum terletak pada perbedaan makna keduanya. Bahwa yang dimaksud kesadaran hukum adalah pengetahuan masyarakat akan aturan hukum yang berlaku serta pilihan yang nantinya bergantung pada masing-masing individu untuk mematuhi atau tidak mematuhi peraturan yang ada. Sementara ketaatan hukum merupakan perilaku masyarakat dalam mematuhi peraturan yang ada sebagai akibat dari adanya dorongan berbagai faktor sosial maupun individual yang mampu mempengaruhi perilaku masyarakat itu sendiri. Baik itu didorong oleh faktor karena takut memperoleh sanksi, atau takut hubungan baiknya dengan seseorang menjadi rusak, ataupun memang tumbuh keyakinan dalam diri bahwa menaati peraturan merupakan tindakan yang sudah seharusnya dijalankan.

28 Soerjono Soekanto, 1983, Faktor-Faktor Yang Mempengaruhi Penegakan Hukum, Jakarta: PT Raja Grafindo Persada. hal. 239

29 Achmad Ali, Menjelajahi Kajian Empiris Terhadap Hukum. Jakarta: PT. Yarsif Watampone. Hlm. 192 
Selanjutnya masih kaitannya dengan mengukur efektivitas peraturan perundangundangan, jawaban atas pertanyaan yang berbunyi kapan suatu peraturan perundangundangan dikatakan tidak efektif tentu adalah ketika sebagian besar masyarakat dalam cakupan wilayah berlakunya peraturan tersebut tidak menaatinya. Namun apabila kondisi sebaliknya yang terjadi pada realitas hukum, bahwa sebagian besar populasi masyarakat yang berkepentingan dengan peraturan tertentu ternyata menaati aturan tersebut, maka masih harus dilakukan kajian lebih mendalam menyangkut kualitas efektivitas peraturan perundang-undangan tersebut. Mengingat dari ketiga jenis ketaatan hukum sebagaimana telah diuraikan sebelumnya, bahwa dua diantaranya hanyalah ketaatan yang bersifat Compliance, dan Identification saja. Yang berarti apabila ketaatan mayoritas penduduk didasarkan atas dua jenis sifat ketaatan tersebut, maka kualitas efektivitas peraturan perundangan dapat diartikan masih rendah. Berbeda apabila mayoritas masyarakat memiliki sifat ketaatan yang terakhir, yakni internalization, maka kualitas efektivitas hukumnya adalah tinggi.

Efektivitas hukum jika dipandang dari perspektif kacamata optik ilmu sosiologi hukum memang akan menghasilkan spektrum pemikiran yang beragam. Hal ini mungkin terjadi mengingat hasil pemikiran para penganut aliran sosiologi hukum memang meliputi beberapa pendekatan yang tidak homogen. Seringkali penyematan judul yang sangat general dilakukan pada hampir seluruh pemikiran sosiologis. Hal ini dilakukan atas dasar perhitungan bahwa sosiolog hukum selalu meneliti efek hukum bersamaan dengan meneliti masyarakat hukumnya secara timbal balik. Judul yang bersifat general bermaksud untuk menggunakan suatu pendekatan yang mampu menuangkan makna bahwa hukum merupakan sebuah fenomena empiris, yang sifatnya hanya dapat dipahami apabila hukum tersebut dilihat dari perspektif hubungannya dengan masyarakat. ${ }^{30}$

Para ahli sosiologi hukum memiliki pendapat bahwa dalam suatu masyarakat modern, peraturan hukum terbagi atas dua klasifikasi. Yaitu aturan sosial dan aturan moral. Anwarul Yaqin (dalam Achmad Ali) menyatakan bahwa hal tersebut dapat terjadi karena masyarakat modern memiliki sistem pemerintahan yang tertata rapi, perangkat pengadilam, serta danya pencatatan adminsitrasi di mana ketaatan terhadap hukum dijamin melalui ancaman sanksi. Sementara dalam peradaban masyarakat primitif yang sederhana, Such Societies have in fact existed and even now (masyarakat yang bukan saja pernah ada tetapi masih ada sekarang, masyarakat yang seperti itu tidak memiliki organisasi, sulit pula memisahkan antara yang mana aturan sosial dan yang mana aturan hukum.

Pendapat Anwarul Yaqin lebih lanjut sehubungan dengan hal diatas, bahwa walaupun hukum dapat eksis tanpa adanya suatu negara yang berdaulat sebagaimana pernah diterapkan pada hubungan keluarga primitif, namun hukum dalam pandangan modern juga termasuk eksistensi negara. Agar rakyat dari negara tersebut dapat hidup tertib, aman, dan damai maka disinilah peranan negara untuk menciptakan situasi yang kondusif sebagaimana yang dicita-citakan, yaitu dengan membentuk suatu aturan berupa peraturan perundangan yang juga disebut sebagai hukum. Didalam aturan-aturan tersebut dapat disisipkan ketentuan sanksi dalam bentuk paksaan untuk melaksanakan ketaatan hukum ${ }^{31}$

30 Ibid, hlm. 180

31 Ibid.Hal. 186 
Unsur paksaan mengambil peranan absolut harus ada agar suatu kaidah dapat dikategorikan sebagai hukum, maka keberadaan unsur paksaan ini selalu memiliki hubungan keterkaitan yang erat dengan ukuran efektif atau tidaknya suatu ketentuan dalam peraturan perundang-undangan. Karena ini lah banyak pertanyaan yang menyasar pada bagaimana ancaman sanksi yang diatur didalam peraturan tersebut apabila peraturan dirasa kurang efektif. Sehingga dapat disimpulkan bahwa salah satu faktor penyebab tidak efektifnya peraturan hukum tersebut karena ancaman paksaannya kurang mengancam (kurang berat) atau karena faktor lain seperti mungkin saja sanksi dalam aturan kurang disosialisasikan, dan kurang dikomunikasikan secara memadat pada warga masyarakat.

Pada akhirnya peranan masyarakat dalam memilih sikap berperilaku sehari-hari menjadi kunci utama bagaimana kebiasaan, trend, pola perilaku sosial masyarakat dapat terbentuk. Sebaik apapun susunan peraturan hukum yang ada tidak akan efektif tanpa adanya daya dan upaya dari masyarakat untuk menegakkan peraturan tersebut. Menumbuhkan kesadaran dan ketaatan hukum bagi tiap-tiap masyarakat menjadi unsur paling penting bagi terwujudnya efektivitas hukum yang dicita-citakan.

Di sisi lain peraturan hukum yang kurang sesuai dengan jiwa bangsa, kebudayaan, ataupun nilai yang tumbuh dan berkembang di tengah masyarakat tidak akan efektif sebaik apapun tujuan pembentukan dan tujuan kandungan pasal-pasalnya. Hal ini lah yang mungkin terjadi dalam penerapan UUHC di Indonesia. Apabila dikaji secara substansial pasal per pasal, hingga ketentuan yang dicantumkan sedikit banyak sudah mengakomodir kebutuhan akan perlindungan Hak Cipta di Indonesia. Bahkan dalam lingkup Internet of Things dibantu dengan eksistensi UU ITE, dan Peraturan Bersama Menteri Hukum dan HAM serta Menteri Kominfo mengenai penutupan/ pemblokiran hak akses dan/atau konten yang diduga melanggar Hak Cipta. Namun, realitas hukum yang terjadi di masyarakat perilaku pembajakan masih belum berkurang.

Faktor sosiologis masyarakat yang berangkat dari kebudayaan, norma sosial, nilai, dan kebiasaan perilaku masyarakat mengambil peranan penuh dimana norma hukum rupanya belum mampu menjalankan tujuannya sebagai a tool of social engineering sebagaimana pendapat yang dikemukakan oleh Roscoe Pound maupun bapak Mochtar Kusuma Atmadja.

Keberadaan peraturan hukum yang baik secara substansi tanpa menyesuaikan dengan nilai-nilai asli yang diakui ditengah masyarakat rupanya tidak mampu menciptakan situasi yang menjadi tujuan dari dibentuknya peraturan tersebut. Apabila dilakukan penelusuran secara historis mengenai pembentukan UUHC, peraturan ini bermula dari adaptasi Perjanjian TRIP's WTO hasil konvensi internasional di bidang hak kekayaan intelektual. Terdapat dua multilateral institution yang menangani persoalan HKI, yaitu TRIP's dan WIPO. WIPO berada dalam naungan lembaga Internasional PBB sementara TRIP's merupakan hasil dari pengakomodasian WTO atas Putaran Uruguay. WTO yang diketahui dengan kepanjangan World Trade Center Organization adalah suatu bentuk lembaga perekonomian internasional yang khusus dibentuk guna mengakomodasi perekonomian global menggunakan standarisasi tingkat regional dan internasional. ${ }^{32}$ Melakukan adaptasi suatu peraturan hasil konvensi internasional

32 Sri Mulyani, "Pengembangan Hak Kekayaan Intelektual Sebagai Collateral (Agunan) Untuk Mengdapatkan Kredit Perbankan Di Indonesia". Jurnal Dinamika Hukum, Volume 12, Nomor 3, 2012, hlm. 1. 
seharusnya membutuhkan adjustment penyesuaian terhadap nilai-nilai asli yang sudah sejak lama mengakar di Indonesia.

Pembajakan merupakan masalah yang sudah mengakar sejak lama bahkan sebelum hadirinya UUHC di tengah masyarakat. Kehadiran UUHC oleh pemerintah mungkin dimaksudkan untuk dapat mengatasi permasalahan tersebut. Hal ini karena pada sektor karya cipta yang juga meliputi penciptaan film memang sangat membutuhkan peran negara untuk turut turut campur guna menciptakan keseimbangan antara kepentingan pemegang hak cipta dengan kepentingan masyarakat. ${ }^{33}$ Namun ternyata UUHC yang tergolong baru menapaki rutinitas masyarakat Indonesia membutuhkan upaya ekstra agar keberadaannya dapat berguna optimal dan efektif.

Pemerintah disamping menguatkan penegakan hukumnya, juga perlu untuk membangun kesadaran dan ketaatan hukum masyarakat. Sinergitas antara keberadaan aturan hukum yang baik dengan perilaku masyarakat memegang peranan penting untuk menciptakan perlindungan hukum yang efektif bagi hak cipta karya sastra film. Upaya yang dapat diupayakan untuk merubah perilaku masyarakat dapat dilakukan melalui langkah-langkah persuasif seperti memberikan edukasi ke masyarakat melalui iklan di televisi, media sosial yang mengajak masyarakat untuk menonton secara legal, ${ }^{34}$ atau dengan melakukan campaign menggandeng sineas-sineas tanah air agar membuat film-film pendek yang menyisipkan nilai-nilai yang mampu menanamkan semangat anti pembajakan, serta budaya menghargai karya-karya anak bangsa. Upaya-upaya tersebut dilakukan demi membangun sinergi antara eksistensi peraturan hukum yang ada dengan perilaku masyarakat. Sehingga perlindungan hukum bagi hak cipta karya sastra film nasional dapat segera diwujudkan secara logis dan tidak akan menjadi cita hukum yang utopis semata.

\section{Kesimpulan}

Perlindungan hukum terhadap pemegang hak cipta khususnya bagi para pemegang hak cipta atas karya sastra film di Indonesia sudah dijamin oleh seperangkat peraturan perundangundangan yang menjadi alat bagi pemerintah untuk melakukan upaya preventif dan represif bagi pelaku pelanggar hak cipta di dunia per film an nusantara. UU Nomor 28 Tahun 2014 tentang Hak Cipta, Undang-Undang Nomor 8 Tahun 2011 Jo. Undang-Undang Nomor 19 Tahun 2016 tentang Informasi dan Transaksi Elektronik, serta Peraturan Bersama Menteri Hukum dan dan HAM Nomor 14 Tahun 2015 serta Menteri Kominfo Nomor 26 Tahun 2015 tentang Pelaksanaan Penutupan Konten dan/atau Hak Akses Pengguna Pelanggaran Hak Cipta dan/atau Hak Terkait dalam Sistem Elektronik, telah memberikan peranan secara preventif yaitu dengan kehadirannya diharapkan mampu memberi ancaman bagi para calon pelaku pelanggar hak cipta berupa deterrence effect atau efek yang mampu menimbulkan ketakutan bagi para calon pelaku melihat ancaman sanksi yang tertera dalam ketentuan peraturan hukum yang berlaku tersebut.

Tinjauan sosiologi hukum terhadap efektivitas UUHC secara umumnya, dan seperangkat peraturan lainnya secara khusus terhadap penindakan bagi para pelaku pelanggar hak cipta

33 Gatot Supramono, Hak Cipta dan Aspek-Aspek Hukumnya, Jakarta: PT.Rineka Cipta, 2012, hlm. 3

34 Robby Noviandy, "Perlindungan Hukum Bagi Pencipta Film Terhadap Situs Penyedia Jasa Unduh Film Gratis di Media Internet”, Jurnal Universitas Atma Jaya Yogyakarta Vol. 2 2016. Hlm. 7 
dalam hak cipta atas karya-karya film nusantara hingga detik ini belum dapat dikatakan efektif melihat realita kegiatan pembajakan yang masih banyak dan kian menjamur di seluruh tanah air, bahkan dengan perkembangan modus maupun media penyebaran film yang semakin canggih hingga bahkan saat ini platform media sosial berbasis aplikasi penyedia layanan perpesanan privat juga menjadi salah satu media penyalur film-film bajakan. Kesadaran dan ketaatan hukum masyarakat menjadi kunci efektif atau tidaknya suatu peraturan hukum. Karena pada akhirnya peranan masyarakat dalam memilih sikap berperilaku sehari-hari menjadi kunci utama bagaimana kebiasaan, trend, pola perilaku sosial masyarakat dapat terbentuk. Sebaik apapun susunan peraturan hukum yang ada tidak akan efektif tanpa adanya daya dan upaya dari masyarakat untuk menegakkan peraturan tersebut.

Peraturan hukum yang kurang sesuai dengan jiwa bangsa, kebudayaan, ataupun nilai yang tumbuh dan berkembang di tengah masyarakat tidak akan efektif sebaik apapun tujuannya. Secara historis mengenai pembentukan UUHC, peraturan ini bermula dari adaptasi Perjanjian TRIPs WTO hasil konvensi internasional di bidang hak kekayaan intelektual. Melakukan adaptasi suatu peraturan hasil konvensi internasional seharusnya membutuhkan adjustment penyesuaian terhadap nilai-nilai asli yang sudah sejak lama mengakar di Indonesia. Pemerintah disamping menguatkan penegakan hukumnya, juga perlu untuk membangun kesadaran dan ketaatan hukum masyarakat melalui langkahlangkah persuasif dengan menggandeng sineas-sineas tanah air untuk melakukan semacam sosialisasi untuk menanamkan semangat anti pembajakan, semangat menghargai karyakarya anak bangsa sehingga nantinya sinergi antara eksistensi peraturan hukum yang ada dengan perilaku masyarakat depat segera terwujud. Cita hukum perlindungan terhadap hak cipta bagi karya sastra film nasional bukanlah hal yang utopis melainkan logis untuk dicapai.

\section{Daftar Pustaka}

\section{Buku}

Achmad Ali, Menjelajahi Kajian Empiris Terhadap Hukum. Jakarta: PT. Yarsif Watampone.

Budi Santoso, 2011, HKI Hak Kekayaan Intelektual, Semarang: Penerbit Pustaka Magister.

Gatot Supramono, 2012, Hak Cipta dan Aspek-Aspek Hukumnya, Jakarta: PT.Rineka Cipta.

Haris Munandar dan Sally Sitanggang. 2011. Mengenal HAKI Hak Kekayaan Intelektual. Jakarta: Penerbit Erlangga.

Henry Soelistyo, 2011, Hak Cipta Tanpa Hak Moral, Jakarta: PT. Raja Grafindo Persada.

Muchsin, 2003, Perlindungan dan Kepastian Hukum bagi Investor Indonesia, Surakarta: Fakultas Hukum Sebelas Maret.

Muhammad Djumhana, 2003, Hak Milik Intelektual Sejarah, Teori dan Prakteknya di Indonesia, Bandung: PT Citra Aditya Bakti.

Peter Mahmud Marzuki, 2018, Penelitian Hukum, Jakarta: Kencana Prenadamedia. 
Ras Elyta Ginting, 2012, Hukum Hak Cipta Indonesia (Analisis Teori dan Praktik), Bandung: Citra Aditya Bakti.

Soerjono Soekanto, 1983, Faktor-Faktor Yang Mempengaruhi Penegakan Hukum, Jakarta: PT Raja Grafindo Persada.

\section{Jurnal}

Aan Priyatna, "Penegakan Hukum terhadap Pelanggaran Hak Cipta dalam Pembuatan E-book", Jurnal Universitas Diponegoro, 2016.

Anak Agung Mirah Satria Dewi, "Perlindungan Hukum Hak Cipta Terhadap Cover Version Lagu di Youtube” Jurnal Magister Hukum Udayana, 06(04), 2017.

Bimo Mahendra, "Eksistensi Sosial Remaja Dalam Instagram (Sebuah Perspektif Komunikasi), Jurnal Visi Komunikasi Volume 16, Nomor 01, Mei 2017, hlm. 152.

Cintya Farha Indah, "Perlindungan Hukum Pemegang Hak Cipta Terhadap Situs Film Gratis di Internet", Jurnal Unisma, Vol. 1 (2020).

Daniel Andre Stefano, Hendro Saptono, dan Siti Mahmudah, "Perlindungan Hukum Pemegang Hak Cipta Film Terhadap Pelanggaran Hak Cipta Yang Dilakukan Situs Penyedia Layanan Film Streaming Gratis di Internet Menurut Undang-Undang Nomor 28 Tahun 2014 Tentang Hak Cipta”, Diponegoro Law Journal, Volume 5 Nomor 3, Tahun 2016.

Fransin Miranda Lopes, " Penegakan Hukum Terhadap Pelanggaran Hak Cipta di Bidang Musik dan Lagu”, Jurnal Hukum, vol. 1 No. 2, Juni 2015.

Fransin Miranda Lopes, “ Penegakan Hukum Terhadap Pelanggaran Hak Cipta di Bidang Musik dan Lagu”, Jurnal Hukum, vol. 1 No. 2, Juni 2015.

Irham Nur Anshari, "Memahami Pembajakan Digital Dalam Budaya Mengopi Video di Warnet", Jurnal Universitas Ahmad Dahlan, 2016.

M. Husein Maruapey, "Penegakan Hukum dan Perlindungan Negara", Jurnal Ilmu Politik dan Komunikasi, Volume VII, Nomor 1, Juni 2017.

Nevey Varida Ariani, “Alternatif Penyelesaian Sengketa Bisnis Di Luar Pengadilan”, Jurnal Rechts Vinding Volume 1, Nomor 2, Agustus 2012, hlm. 4.

Oksidelfa Yanto, "Konsep Perlindungan Hak Cipta dalam Ranah Hukum Hak Kekayaan Intelektual (Studi Kritis Pembajakan Karya Cipta Musik dalam Bentuk VCD dan DVD)" Yustitia Jurnal Fakultas Hukum Universitas Sebelas Maret, 04(03), 2015.

Robby Noviandy, "Perlindungan Hukum Bagi Pencipta Film Terhadap Situs Penyedia Jasa Unduh Film Gratis di Media Internet", Jurnal Universitas Atma Jaya Yogyakarta Vol. 2 2016.

Sri Mulyani, "Pengembangan Hak Kekayaan Intelektual Sebagai Collateral (Agunan) Untuk Mengdapatkan Kredit Perbankan Di Indonesia”. Jurnal Dinamika Hukum, Volume 12, Nomor 3, 2012.

Thalib Prawitri, "Perlindungan Hukum Terhadap Pemegang Hak Cipta dan Pemilik Lisensi 
Rekaman Berdasarkan Undang-Undang Tentang Hak Cipta." Jurnal Yuridika. Vol 23 No. 8, September-Desember 2013.

Wempi JH Kumendong, "Kemungkinan Penyidikan Delik Aduan Tanpa Pengaduan”, Jurnal Hukum Universitas Sam Ratulangi, Volume 23, Nomor 9, April 2017.

\section{Skripsi, dan Tesis}

Hasbir, 2002, Analisis Aspek Sosiologi Hukum Terhadap Pelanggaran Hak Cipta Rekaman Suara (lagu) di Kota Makassar, Tesis.

Mega Silvana Kurniawati, 2015, "Konsekuensi Perubahan Sifat Delik Pelanggaran Hak Cipta Terhadap Perlindungan Pencipta Menurut Undang-Undang Nomor 28 Tahun 2014 Tentang Hak Cipta", (Skripsi Fakultas Hukum Universitas Atma Jaya Yogyakarta).

\section{Peraturan Perundang-Undangan}

Undang-Undang Nomor 28 Tahun 2014 Tentang Hak Cipta

Undang-Undang Nomor 8 Tahun 2011 Jo. Undang-Undang Nomor 19 Tahun 2016 Tentang Informasi dan Transaksi Elektronik

Peraturan Bersama Menteri Hukum dan HAM Nomor 14 Tahun 2015 dan Peraturan Menteri Kominfo Nomor 26 Tahun 2015 Tentang Pelaksanaan Penutupan Konten dan/atau Hak Akses Pengguna yang Melanggar Hak Cipta dan/atau Hak Terkait dalam Sistem Elektronik.

Kitab Undang-Undang Hukum Perdata

\section{Sumber Lainnya}

Ahmad M. Ramli, September 2018 "Perlindungan Hak Cipta Terhadap Film Berdasarkan Undang-Undang Nomor 28 Tahun 2014" online document, http://docplayer.info/ storage/70/6231381/62131381.pdf, diakses 27 Desember 2020.

Hari Widowati, "10 Keunggulan Telegram Aplikasi Perpesanan Pesaing Whatsapp”, 23 Mei 2019, https://katadata.co.id/hariwidowati/digital/5e9a518a845d1/ini-10-keunggulantelegram-aplikasi-perpesanan-pesaing-whatsapp, diakses pada 29 Desember 2020.

RetiaKartikaDewi, "Sutradara StoryofKaleakanPolisikanPembajakFilmini SanksiHukumnya", 27 Oktober 2020,https://www.kompas.com/tren/read/2020/10/27/215706265/sutradarastory-of-kale-akan-polisikan-pembajak-film-ini-sanksi-hukumnya?page=all, diakses pada 22 Desember 2020. 